\title{
Filles Eveillées ('Girls awakened'): A pilot program for migrant adolescent girls in domestic service in urban Burkina Faso
}

\author{
Sarah Engebretsen \\ Population Council \\ Gisele Kaboré \\ Population Council \\ Leah Jarvis
}

Follow this and additional works at: https://knowledgecommons.popcouncil.org/departments_sbsr-pgy

Part of the Demography, Population, and Ecology Commons, Family, Life Course, and Society Commons, Gender and Sexuality Commons, International Public Health Commons, Medicine and Health Commons, and the Women's Health Commons

How does access to this work benefit you? Let us know!

\section{Recommended Citation}

Engebretsen, Sarah, Gisele Kaboré, and Leah Jarvis. 2012. "Filles Eveillées ('Girls awakened'): A pilot program for migrant adolescent girls in domestic service in urban Burkina Faso." New York: Population Council. 


\section{FILLES EVEILLÉES (“GIRLS AWAKENED”)}

A PILOT PROGRAM FOR MIGRANT ADOLESCENT GIRLS IN DOMESTIC SERVICE IN URBAN BURKINA FASO

SARAH ENGEBRETSEN, GISELE KABORÉ, AND LEAH JARVIS

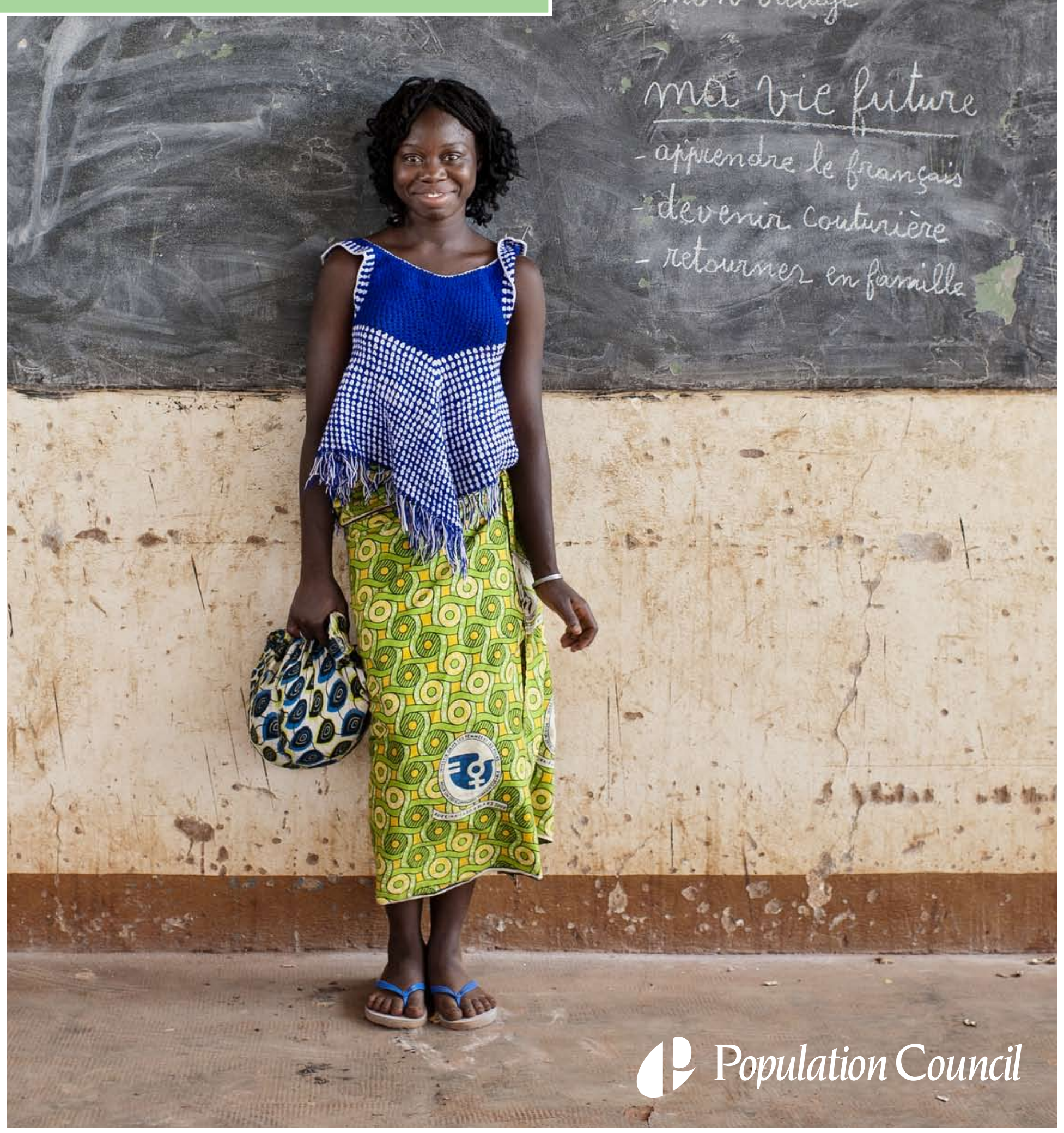




\section{Population Council}

The Population Council confronts critical health and development issues-from stopping the spread of HIV to improving reproductive health and ensuring that young people lead full and productive lives. Through biomedical, social science, and public health research in 50 countries, we work with our partners to deliver solutions that lead to more effective policies, programs, and technologies that improve lives around the world. Established in 1952 and headquartered in New York, the Council is a nongovernmental, nonprofit organization governed by an international board of trustees.

(C) 2012 The Population Council, Inc.

Population Council

One Dag Hammarskjold Plaza

New York, NY 10017 USA

Tel: 212-339-0500

Fax: 212-755-6052

http://www.popcouncil.org

Sarah Engebretsen is a Program Manager at the Population Council in New York, and Gisele Kaboré is a Project Coordinator at the Population Council in Burkina Faso. Leah Jarvis is currently a graduate student at Columbia University who interned at the Population Council's Burkina Faso office.

Photographer: Ollivier Girard 
Young people in Burkina Faso have few economic opportunities, particularly in rural areas. This is especially true for adolescent girls, who typically have very little schooling or other preparation to take up work. This lack of economic opportunities in rural areas drives migration to urban areas in search of employment. For many girls, the chance to work in an urban area in domestic service is an opportunity to earn money, often to purchase supplies in preparation for marriage.

In 2010, the Population Council conducted formative research to better understand the situation of migrant adolescent girls in domestic service in urban Burkina Faso. Findings revealed that once girls arrive in the city, they typically live with their employers and spend long days performing arduous work. This leaves them with little time for schooling, building social networks, and developing skills necessary for adulthood. The formative research also showed that girls' migration is typically seasonal; girls live and work in cities during the dry season and return home each year to help out with agricultural tasks during the rainy season. Furthermore, the research revealed that the majority of programs designed for this population: intervene after something has gone wrong rather than building girls' protective assets; focus on teaching girls about their rights rather than imparting skills; are not designed around logical age segments; and focus on inputs (i.e., number of radio messages delivered) rather than measurable change at the level of the

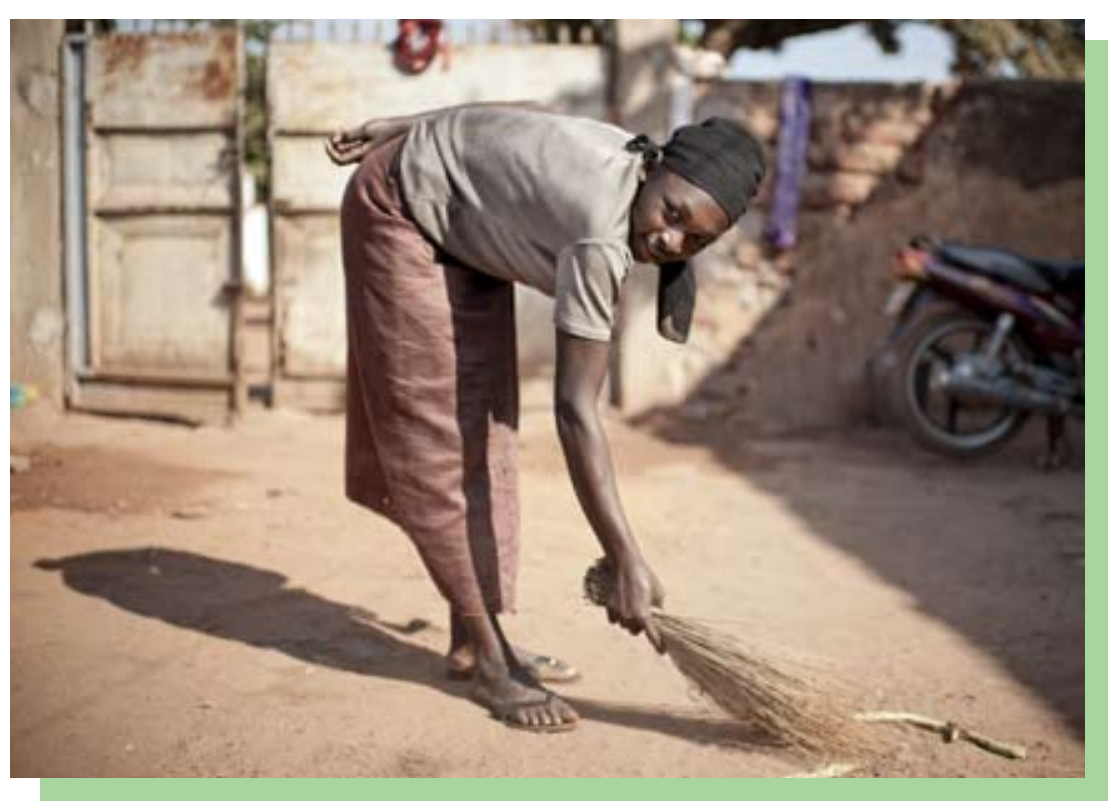
girl.

\section{THE FILLES EVEILLÉES PROGRAM}

In response to these findings, the Population Council designed an eight-month, 30-session intervention for migrant adolescent domestic workers in urban Burkina Faso. Filles Eveillées ("Girls Awakened") aims to increase social capital; build adolescent girls' skills in health (including sexual and reproductive health), life skills, and financial capabilities; and link girls to services. By providing girls with a safe space, access to peers, and a female mentor, this 
program seeks to increase domestic workers' opportunities and reduce their vulnerabilities. The 2011-13 pilot program will reach 375 girls and has two program cycles. The 2011-12 cohort was conducted in Bobo-Dioulasso in partnership with Association Tié and included girls 11-16 years old. The 2012-13 cohort will include girls up to age 18 in Ouagadougou, in partnership with the Association d'Appui et d'Éveil Pugsada.

This Program Brief describes the Filles Eveillées program model and the lessons learned from the 2011-12 cohort. Findings from this brief are drawn from a pre-test/post-test with program participants (Engebretsen 2012), subsequent focus group discussions (Kabore 2012), and a process evaluation designed to evaluate program implementation with the first cohort (Jarvis and Kabore 2012).

\section{DOOR-TO-DOOR RECRUITMENT TO REACH THE MOST SOCIALLY ISOLATED}

Filles Eveillées is led by female mentors drawn from intervention communities, who are 20-30 years of age, able to speak the local language, and have achieved at least a few years of secondary education. The mentors are both old enough to give advice to girls in the program and young enough so program participants can identify with them.

Mentors are trained on a skills-based curriculum that focuses on life skills, health and hygiene, sexual and reproductive health, and financial capabilities. Following training, mentors go door to door to identify girls eligible for program participation: those who are 11-16 years old and employed as domestic workers in one of the selected project sites. Both participants and employers are asked to sign the program permission form and to consent to girls' participation in program surveys.

"It's because we feel comfortable with our mentor that we come and tell her what we think. With her, there's more security in communicating-you consider her like a friend."

15-YEAR-OLD PARTICIPANT

\section{COMMUNITY ENGAGEMENT}

Before launching Filles Eveillées, program staff meet with community leaders to introduce the program, identify safe spaces where the program can be held, and respond to community concerns. Community awareness sessions are held three times during the course of the eight-month intervention to introduce community members to the goals and expectations of the program, update them on what girls are learning, hear testimonials from girl participants, and respond to any questions or concerns.

"The community sessions permitted the population to know that there are children like domestic employees who also have rights we should respect. The leaders are very involved in the program [as are] the people."

MALE COMMUNITY MEMBER

"Our relationships with employers have changed. At the beginning they were reticent, but after home visits they understood and let us participate in the program." 


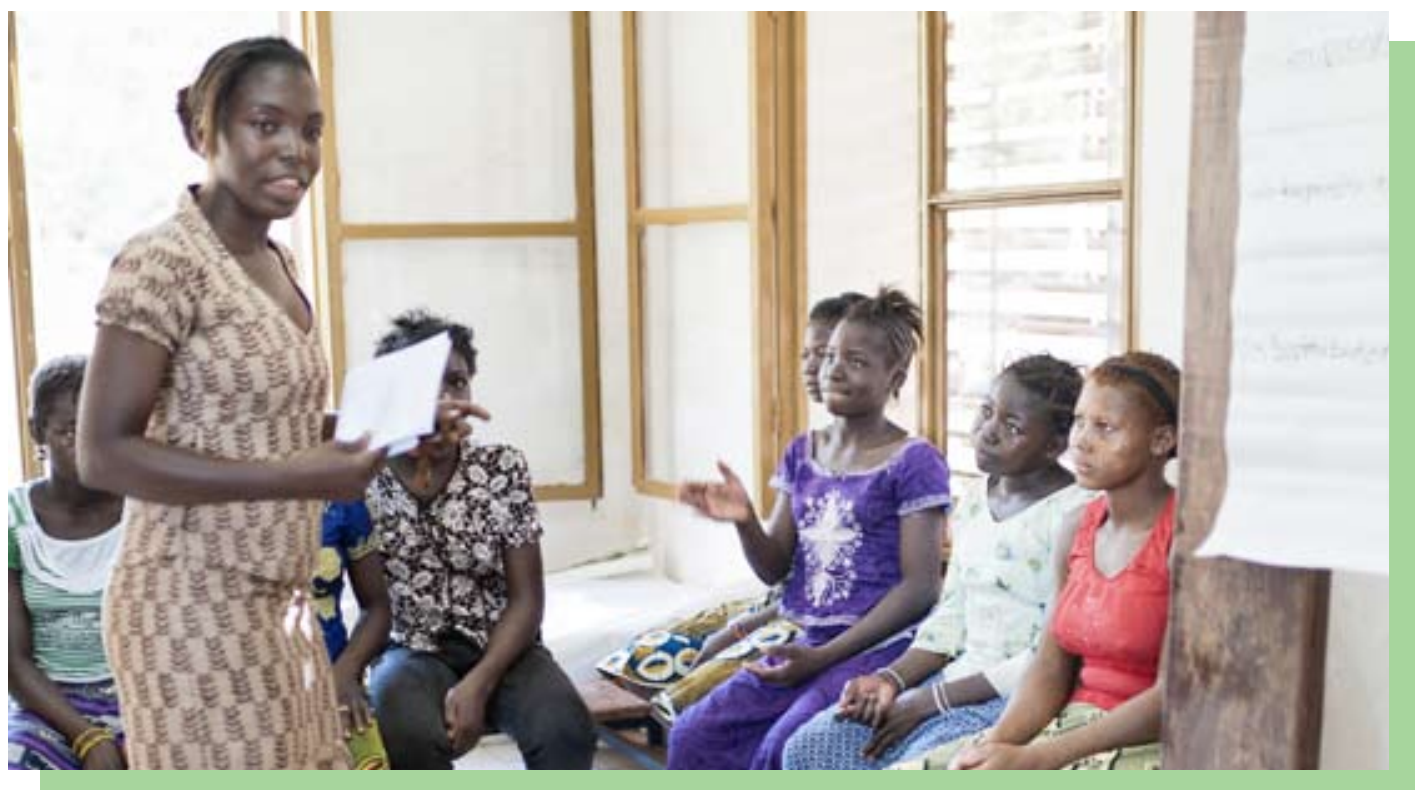

Mentors additionally make three home visits to each girl during the course of the eightmonth intervention to strengthen the relationship between the mentor and the employer, strengthen the relationship between the employer and employee, and keep the employer informed of the program and the employee's progress.

\section{REGULAR GROUP MEETINGS}

Due to the time constraints of this target population, groups meet once a week on Sundays for about two hours. Groups are held in empty classrooms in local schools, in municipal buildings, at local NGOs, and in semi-enclosed courtyards. Sessions are designed to be interactive and utilize group discussions, personal stories, exercises, and role-playing. On average, participants in Filles Eveillées' first cohort attended 22 out of 30 sessions. Seventy-two percent attended at least 20 of the sessions, and one in five girls attended all 30 sessions. In addition to these weekly sessions, girls who have never been to school or who have not finished school are given the opportunity to gain primary or secondary education through cours du soir (evening classes), which likely contributed to the improved literacy levels observed from baseline to endline.

"Before, I had never been to school, but thanks to the program I learned to read and write."

16-YEAR-OLD PARTICIPANT

\section{ENGAGING A MOBILE POPULATION}

This program was designed to coincide with the seasonal migration of the target population and reach girls when they are living and working in cities. Participants from the program's first cohort were found to be highly mobile, and internal migration was far more common than international as is typical among adolescent girls (Temin, Montgomery, Engebretsen, and Barker, forthcoming). The majority of participants were born in Burkina and moved to BoboDioulasso. More than 60 percent at baseline reported living in their current neighborhood for less than one year. Four-fifths of the girls reported moving to the city for economic and employment reasons. 


\section{BUILDING SOCIAL CAPITAL AND LIFE SKILLS}

Filles Eveillées provides girls with opportunities to expand their social networks by participating in same-sex groups led by female mentors. Migrant adolescent girls in domestic service are isolated from their peers; at baseline, 95 percent of participants reported not being part of any social groups, suggesting that Filles Eveillées was their sole opportunity for group affiliation. At endline, almost all respondents agreed with the statement that they had more friends now as a result of the program. Despite isolation from same-sex peers, these girls have regular contact with extended family members, those who helped them find employment, and those who provided housing when the girls first arrived at their destination.

Positive changes were observed from baseline to endline in participants' reported social capital as measured by the questions "Has a safe place to meet friends?" "Has someone to borrow money from in an emergency?" and "Has people to talk to for advice?"

"When work finishes, I ask my employer for permission to visit the person who helped me get the job."

13-YEAR-OLD PARTICIPANT

In addition to expanding social networks, the program was designed to improve girls' ability to express themselves and build self-confidence; changes reported over time in these domains are included in Figure I.

FIGURE 1: Percentage of surveyed girls in the Filles Eveillées program, by self-confidence measures, according to time of survey

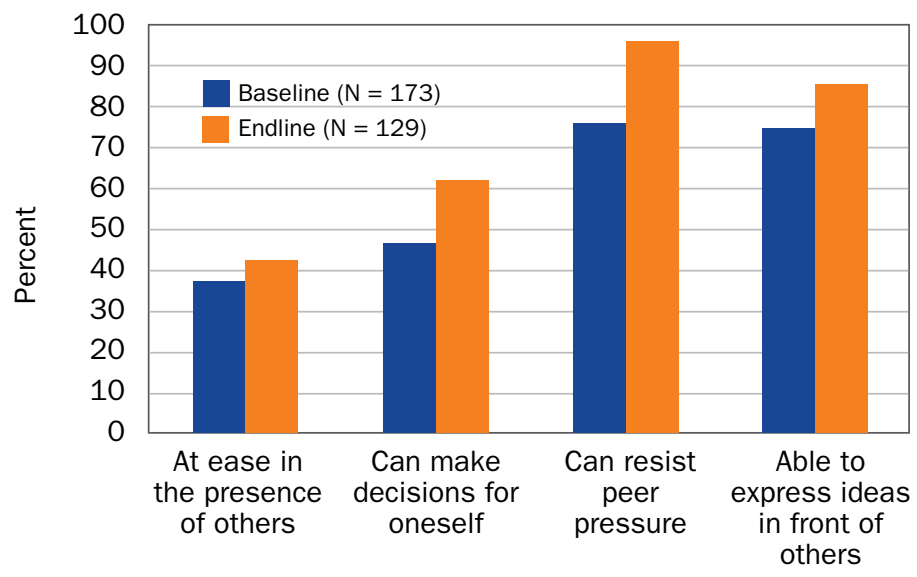

\section{IMPROVING HEALTH AND HYGIENE}

Filles Eveillées provides program participants with opportunities to learn about important topics related to health and hygiene, though knowledge of hygiene was high even at baseline.

The program also gives girls skills to manage their own health. Positive changes were observed in awareness of steps to be taken to improve one's health; at baseline, only 10 percent knew that a girl could perform a breast self-exam compared with 54 percent at endline. The post-test showed that almost all girls agreed that they could better manage their health after participating in Filles Eveillées.

Filles Eveillées explores attitudes concerning health-seeking behavior. About one-half of cohort 1 participants reported visiting a health center when they were ill. Reasons cited for not visiting a health center in such cases included not having enough money, not feeling sick enough to seek care, and believing that health centers are reserved exclusively for welleducated people. When asked why some girls their age visit health centers, only 12 percent 
of baseline respondents knew that health centers can provide health information, but this increased to 50 percent at endline.

"[Our employee] changed physically in terms of hygiene. I noticed that after using the toilet she washes her hands. She's become very clean. And then she shares her knowledge about diseases and HIV with my daughters. That really pleased me."

EMPLOYER

\section{ADDRESSING SEXUAL AND REPRODUCTIVE HEALTH}

Formative research findings demonstrated that girls in domestic service lack sexual and reproductive health knowledge and that employers don't feel equipped to discuss this topic with them.

Filles Eveillées was designed to provide girls with information on sexual and reproductive health including services available in their communities. Sexual and reproductive health knowledge improved from the pre-test to the post-test in items such as knowing when during the menstrual cycle a woman can get pregnant, how to avoid HIV, symptoms of STIs, and various family planning methods. Participants report that when they do have the occasion to interact with other adolescent domestic workers, they often discuss matters of health and hygiene.

In addition to increasing knowledge, the program aimed to make girls aware of available health services in their neigborhoods. Awareness of at least one place in the community that provided family planning methods increased from 67 percent at baseline to 91 percent at endline. Knowledge of where to go within the community in the event of rape or harassment was less than one-fifth at baseline and improved to almost one-half at endline.

"We're really embarrassed to talk about sexuality with our girls. We never give information regarding menstruation. When they go to the sessions, they learn a lot of things there. l'm really happy."

FEMALE EMPLOYER

"We give each other advice concerning boys, contraceptives, and other things to avoid illness and improve hygiene."

16-YEAR-OLD PARTICIPANT

\section{DEVELOPING GIRLS' FINANCIAL CAPABILITIES}

Girls in domestic service are already economically active, and Filles Eveillées develops their capabilities in saving and budgeting and their ability to talk about money and plan for their financial future. Cohort 1 girls reported spending their money on things such as cosmetics, clothing, preparing for marriage, and sending remittances home to family.

Girls' savings behaviors improved from baseline to endline, and at endline girls were more likely to report saving for emergencies and problems than at baseline.

Other notable reasons for saving included buying personal items and sending money to family members. Girls gave a variety of responses to where they keep their savings; some 


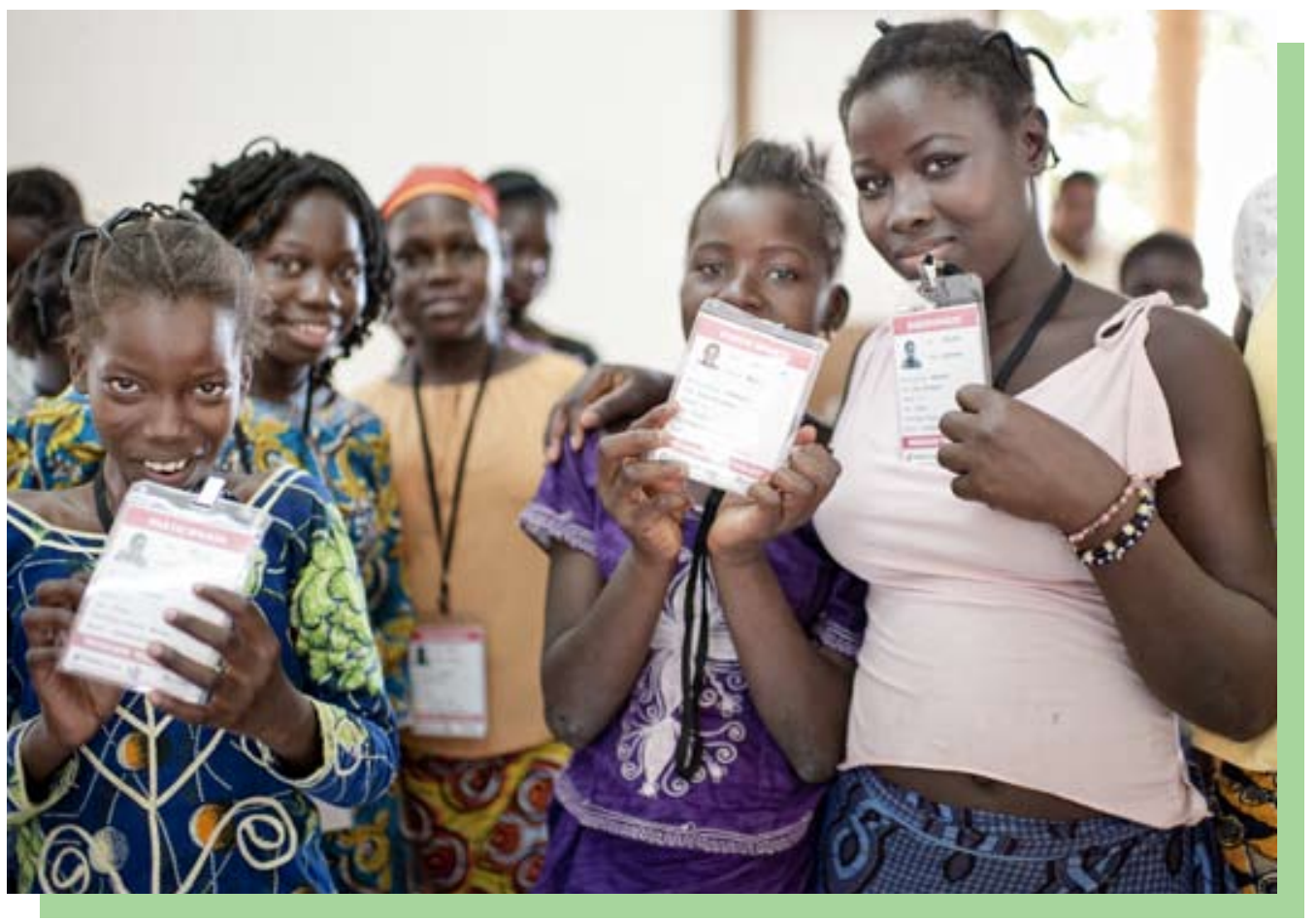

reported asking employers to help them set aside their savings in a safe place, although this strategy often backfired. Of note, the percentage of girls saving in a bank or through a tontine increased from baseline to endline. The legal age in Burkina for opening a bank account and independently making transactions is 21 years, although those younger than 21 can have accounts if they have parental permission. However, because these girls have often migrated away from home and family, some lack access to adults who can help them establish bank accounts.

Likewise, girls' reported improvement in savings goals from baseline to endline. Common short-term goals were buying clothes and cosmetics, and common long-term goals were establishing one's trousseau and financial preparation for marriage. Girls' reported ability to talk with employers about money also improved from baseline to endline (49-78 percent).

"I stay in touch [with my family in the village] to know if everyone is doing $\mathrm{OK}$ and if there are difficulties such as not enough food or money. In that case, I send them money."

13-YEAR-OLD PARTICIPANT

"I am preparing for my future and saving a little so I can address illness and other problems."

13-YEAR-OLD PARTICIPANT

“In the big cities, one doesn't always know someone. And then you have to wait for a guardian to go and withdraw money. Often this moment never arrives, and we need money immediately." 


\section{LESSONS LEARNED AND CHARTING A PATH FORWARD}

The evaluation of Filles Eveillées' first cohort shows early success in engaging the target population. Despite their busy schedules, migrant adolescent girls in domestic service are interested in the program and regularly attend weekly sessions. Findings from the cohort 1 evaluation showed measurable improvement at the level of the girl in all outcomes of interest.

As a pilot program, it is inevitable that obstacles would be encountered in Filles Eveillées' first iteration. Having two serial cohorts in the program allows the research and program team to test the program model and data collection instruments, reflect on cohort 1 findings, and make adjustments to the program before launching the second cohort.

One course correction that the program team made was refining the curriculum in terms of organization, content (with particular attention to illiteracy among the target population), and extra resources and exercises to reinforce learning. Given girls' interest in developing financial capabilities, it was decided to move this section toward the beginning of the curriculum so that girls can be encouraged to exercise their skills in savings, and mentors can more closely monitor progress. The program team is currently developing a toolkit that will allow program graduates to pass on their knowledge to peers and other girls in their urban neighborhoods and villages.

In addition to revising the curriculum, the Filles Eveillées team has refined the program model before beginning with the 2012-13 cohort. Recognizing that the success of Filles Eveillées depends on community engagement, the program team has added an element to directly engage employers in a few sessions in addition to their participation in community awareness sessions. Likewise, girl graduates of the program who are still living in the city and engaged in domestic work will serve as assistants to program mentors in the second cohort. In an effort to improve girls' access to services, Filles Eveillées will introduce girls to local health providers and cover the cost of needed health and/or medical services for those who are unable to pay for such care. Finally, given the importance of savings for economically active girls who are living apart from parents, the program team is putting greater emphasis on introducing girls to financial institutions through guided visits with bank staff.

\section{REFERENCES AND RESOURCES}

Engebretsen, Sarah. 2012. “Baseline and Endline Findings of Filles Eveillées (Girls Awakened): A Pilot Program for Migrant Adolescent Girls in Domestic Service. Cohort 1 (2011-2012), BoboDioulasso." New York: Population Council.

Jarvis, Leah and Gisele Kabore. 2012. “Process Evaluation: The Filles Eveillées (Girls Awakened) Program for Migrant Adolescent Girls in Domestic Service in Urban Burkina Faso." Ouagadougou: Population Council.

Kabore, Gisele. 2012. "Réseaux Sociaux et les Capacités Financières des Filles Employées de Maison à Bobo-Dioulasso." Ouagadougou: Population Council.

Temin, Miriam, Mark Montgomery, Sarah Engebretsen, and Kathryn M. Barker. Forthcoming. "Girls on the Move: Adolescent Girls and Migration in the Developing World." A Girls Count Report. New York: Population Council.

\section{DONORS AND PARTNERS}<smiles></smiles>

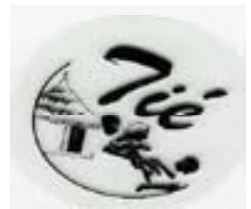

Association d'Appui et d'Éveil Pugsada 
WWW.POPCOUNCIL.ORG 